\title{
Ética Aristotélica em MarX?
}

\author{
Alexandre Lima ${ }^{1}$
}

\begin{abstract}
RESUMO: Alguns filósofos e economistas buscam fundamentar eticamente a economia, a fim de voltar a subordiná-la à política, apelando, inclusive, para uma aproximaçấo entre Marx e Aristóteles a partir da teoria da práxis. Este artigo pretende analisar em que sentido os conceitos aristotélicos de ação, produçáo, ato e potência exercem influência sobre Marx. Afirma que, contrariamente ao que muitos filósofos da moral defendem, são as investigaçôes de Aristóteles sobre economia que serviram como ponto de partida para a fundamentaçáo da crítica à economia política elaborada por Marx, enquanto que a ética e a política aristotélicas são apenas secundárias para a teoria marxiana.
\end{abstract}

PALAVRAS-CHAVE: Marx. Aristóteles. Ética. Economia. Práxis.

\section{INTRODUÇÃo}

Não é novidade reconhecer que, após o fim do socialismo real, a teoria marxista, de modo geral, caiu no ostracismo: afinal, a grande revolução não aconteceu e, com a impossibilidade de salvar todo o pensamento marxiano, restou sua fragmentação e aproveitamento do que há de mais assimilável às necessidades da filosofia contemporânea, marcada pelo desesperado resgate da antiga soberania da política e da ética. Em meio à crescente preocupação de alguns filósofos e economistas em fundamentar eticamente a economia, a fim de voltar a subordiná-la à política, também têm surgido variadas propostas buscando elementos que aproximem a teoria da práxis de Marx com a de Aristóteles. Para verificar a plausibilidade dessas propostas, seria preciso analisar antes em que sentido os fundamentos das concepçóes econômicas, éticas e políticas, e a inter-relação desses âmbitos nos respectivos filósofos poderiam ou não balizar as pretendidas mudanças - teóricas, obviamente. Nossos objetivos, no entanto, são mais modestos. Vamos tentar identificar, primeiro, se e como

\footnotetext{
${ }^{1}$ Doutor em Filosofia pela Universidade Federal de Santa Catarina - UFSC. Professor do Centro Universitário Municipal de São José - USJ, Santa Catarina.
} 
os conceitos aristotélicos de ação (prâxis), produção (poíesis), ato (enérgeia) e potência (dýnamis) atuam sobre a teoria da práxis de Marx; segundo, mostrar que, contrariamente ao que muitos filósofos da moral defendem, não são as questôes antropológicas, morais ou mesmo políticas que permitem verificar a relevante aproximação entre Marx e Aristóteles, e sim as investigaçóes e as respectivas oscilaçóes conceituais de Aristóteles referentes ao fenômeno da economia, que serviram a Marx como ponto de partida para a fundamentaçáo de sua crítica à economia política.

\section{AÇấo E PRODUÇấo}

Diferentemente de Karl Popper², que enfatizou os elementos antiliberais e antidemocráticos, encontrados tanto em Marx como em Aristóteles, a tendência contemporânea é aproximar esses dois filósofos a partir de conceitos passíveis de incorporação ao discurso filosófico predominante, saudosista das funçóes da política na antiguidade greco-romana. Deixemos os "inimigos da sociedade aberta". Vamos apresentar brevemente as tentativas de alguns filósofos e pesquisadores que, ao aceitarem o capitalismo como intransponível, refugiam-se na aproximação entre Aristóteles e Marx com base no reconhecimento de princípios antropológicos, éticos e políticos, que, de algum modo, seriam coincidentes.

Entre os variados recursos usados para tentar mostrar as similitudes entre os dois filósofos, destaca-se o par conceitual ação/produção, que, para Aristóteles, serve, entre outras coisas, para delimitar e hierarquizar as várias áreas do saber - teoria, prática e produção -, buscando encaixar, nem sempre com sucesso, metafísica, física, política, economia etc., em seus respectivos grupos. Quanto à economia, Aristóteles mostrou-se particularmente confuso devido às ambiguidades presentes nas relaçóes de troca - envolvendo a busca do padrão de comensurabilidade e a distinção entre valor de uso e de troca as quais dificultaram o levantamento de critérios para definir os espaços funcionais existentes entre a arte de administrar as coisas da casa (oikonomia), a arte da aquisição (crematística) e a política. Na Politica (1256a9-15; 1256b401257a5), Aristóteles fixa o escopo da economia, apresentando ainda sua relação com a política - a ciência prática por excelência - e com a crematística

\footnotetext{
${ }^{2}$ Popper (1987) do alto da típica "neutralidade científica" moderna, denomina Platâo, Aristóteles e Marx como verdadeiros inimigos da sociedade aberta, ou seja, inimigos da democracia e liberdade capitalistas.
} 
- uma ciência produtiva que teria uma parte, a crematística natural, inclusa na economia, enquanto a crematística não natural é voltada exclusivamente à permuta, extrapolando os propósitos originais da economia. A confusão surge porque, ao mesmo tempo em que economia pertence e se submete aos ditames da política, uma parte da crematística (a natural) pertence à economia.

Na Ética a Nicômacos (1140b6-9), Aristóteles expóe um dos critérios para a classificação das ciências com base na imanência do fim (télos) na ação: "[...] enquanto o fazer tem um fim diferente de si mesmo, o fim na ação não pode ser senão a própria ação, pois agir é um fim em si”. Tanto as ciências práticas quanto as produtivas se referem às ações, porém, enquanto as práticas se referem às açôes que têm seu início e fim no próprio sujeito que age, as produtivas se referem às açôes que produzem algo fora do sujeito. Política e economia são ciências práticas, porque não produzem um objeto concreto, apenas proporcionam as condiçôes para a realização de um objetivo maior, a felicidade. Entretanto, na economia, a ação está em função de outra ação, a política, que se confunde com a própria felicidade, a ação propriamente dita. A política é igualmente uma ação que está em função de outra, a felicidade, mas há uma diferença crucial. Enquanto na Ética a Eudemo (1242a22-3), Aristóteles afirma que o homem é, também, um animal econômico, um ser da casa, na Política (1253a3-5) deixa claro que "[...] o homem é por natureza um animal político", pois a felicidade só é possível na polis. Portanto, a ação econômica, o gerenciamento da propriedade, está em função da ação política, que é própria ao sujeito, conforme uma hierarquia ontológica: a política é anterior à economia assim como a polis é anterior à casa.

$\mathrm{Na}$ Metafísica, livro IX, Aristóteles enfatiza ainda as relações entre ação/ perfeição e produção/imperfeição a partir da imanência do fim na ação: ação perfeita (téleia) é a ação propriamente dita, coincide com o ato, com o que é real no sentido próprio; ação imperfeita (atelés) tem limite (péras) externo, é transitiva, sinônimo de movimento, e movimento existe sempre em direçáo a um fim diferente da própria ação. Essas relaçóes podem ser mais bem percebidas na Ética a Nicômacos (1097a34-1097b3), onde se destacam dois exemplos de ação: o viver bem e o ser feliz. A felicidade é o fim último do homem, porque todas as outras açôes são exercidas visando a esse bem; é fim em si mesma, perfeita e autossuficiente, expressa o tipo de vida mais desejável e satisfatória conforme escolha racional; não é definida como um processo ou movimento, mas como a própria ação (1099b24-30). A autossuficiência da felicidade é o aspecto que lhe permite a continuidade no tempo, a ausência de limites, por 
isso é ação e não produção. Por exemplo: a ação de pensar, que, ao se confundir com o ato de ter pensado algo, é ação imediata e completa, é um ato o qual está inteiro no agente e não precisa de um objeto para se concretizar. Nas açốes de viver bem, ser feliz e pensar, o tempo presente (pensar) e o tempo passado (pensado) estão unidos, os dois momentos se confundem, são simultâneos, meio e fim coincidem.

Ainda na Ética (1140a12-15), como exemplo de produção, Aristóteles cita a arquitetura, arte cujo fim e meio não coincidem: o construir é sempre com o propósito de erguer uma obra, uma casa, uma ponte etc.; os momentos entre o estar construindo e o já construído são bem delimitados, distintos. Produção é ação imperfeita, porque cessa depois de realizar seu propósito, ninguém continua construindo a casa depois de já ter terminado sua construção. A arte de construir tem como fim (uma casa) algo extrínseco ao próprio exercício da construção.

Construir uma casa ou adquirir um bem (atribuição da crematística) certamente são açóes transitórias, no sentido de que visam a uma finalidade extrínseca, mas como classificar o uso (chreía), a ação de usar que é própria da economia? Os exemplos dados por Aristóteles nem sempre têm a exatidão esperada, contudo, podem ajudar a captar a ideia central do argumento. Nenhuma ação é absolutamente imanente por si mesma ${ }^{3}$, o que determina sua transitoriedade ou imanência é a finalidade. A imanência da ação de usar, o uso que se faz de um bem econômico ganha sentido somente se promover a autarquia do proprietário, a fim de liberá-lo para a ação propriamente dita: a política. Dessa maneira, mesmo a ação da aquisição, específica da crematística, se estiver voltada estritamente ao provimento da casa, também sustentará o aspecto imanente. Assim, ainda que se explorem os exemplos dados por Aristóteles, o máximo que se pode extrair deles é a ideia intuitiva de uma relação subjacente, principalmente quando o objeto de análise são as relações humanas. O propósito é mostrar que a ação está diretamente relacionada com a liberdade, fim em si mesma, enquanto a produção é uma atividade que tem

\footnotetext{
${ }^{3}$ Crespo (2006, p. 6), apresenta a caracterizaçẫo da economia, para Aristóteles, como ação, hábito e conhecimento prático, todas constituindo significados derivados cujo significado "focal" é ação de usar, ontologicamente anterior a essas qualidades. A crematística também é ação humana, mas é uma ação claramente subordinada, enquanto a economia é um hábito o qual facilita o aspecto predominantemente imanente da açăo humana de "usar" a riqueza necessária para o viver em geral e o viver bem, de sorte que o propósito do uso é a própria perfeição. A crematística é uma ciência da produção, enquanto economia é ciência prática: "Todas as açōes são imanentes e transitivas, com exceção do caso de ação plenamente imanente (pensar, amar)".
} 
como fim outra coisa, a ação, por isso a economia está em função da política. Todavia, não é tão simples estabelecer a relação direta entre ação/política, por um lado, e produção/crematística, por outro, pois na economia o "agir em si" (próprio da política) e o "produzir para outro" (próprio da crematística) se confundem, porque, apesar de partilhar o mesmo fim com a política, a economia partilha o mesmo objeto com a crematística: o uso dos bens. A distinção entre ação e produção a partir da noção de limite e imanência pode auxiliar na delimitação do espaço de atuação da economia, porém, ao fazer a distinção entre crematística natural e não natural, sendo que só a primeira pertence plenamente à economia, Aristóteles promove uma cisão que coloca a economia num limbo entre ciência prática e ciência produtiva, malgrado a consideração do télos humano pretenda determinar que a economia deva se submeter à política. Há ainda outro agravante. Como a economia pertence à política e a crematística é parte da economia, o trabalho - mesmo não sendo previsto nem desejado por Aristóteles - acaba se tornando categoria privilegiada, na hora de analisar a abrangência da economia. Com as indecisóes quanto ao aspecto extrínseco ou intrínseco do objeto da economia, o trabalho, de certo modo, parece incorporar ação e produção, o que remete às respectivas concepçóes aristotélicas e marxianas sobre a natureza do trabalho.

\section{A PRÁXIS E OS FILÓSOFOS DA MORAL}

O constrangimento contemporâneo, frente à insubordinação da economia, buscou alternativa na aproximação entre Marx e Aristóteles, chamados para fortalecer aquilo que os filósofos da moral acreditam que restou à filosofia social: análises limitadas à ética e à política ${ }^{4}$. Tem-se ressaltado um discurso moral em Marx, principalmente por conceitos como igualdade, autarquia, livre expressão, entre outros, deixando em segundo plano a crítica à estrutura econômica. Para ilustrar o problema, vamos apresentar algumas dessas abordagens teóricas.

William Booth admite que os pontos mais significativos de Aristóteles os quais exerceram influência direta sobre Marx são a distinção entre valor de troca e valor de uso, e a ideia de que a economia deve ser subordinada à ética e à política. Porém, como sua preocupação é encontrar a relação entre princípios

\footnotetext{
${ }^{4}$ A coletânea de artigos Marx and Aristotle: Nineteenth-century German Social Theory and Classical Antiquity (MCCARTHY, 1992) representa bem tal atitude, com a desinibida defesa da influência da ética, política, antropologia e da metafísica aristotélicas sobre Marx, sem considerar a teoria econômica.
} 
morais e estrutura social na teoria de Marx, Booth focalizou os esforços que, segundo ele, Marx teria feito para construir uma teoria política e econômica baseada no modelo de economia antiga:

Este modo de conceber a economia pré-capitalista - com sua ênfase sobre a finalidade da atividade econômica - Marx adotou de Aristóteles, sobretudo da Política, livro I, em que é definido com inigualável claridade o modelo de economia baseado no oikos. (BOOTH, 1992, p. 244).

Nessa abordagem, o comunismo de Marx não é resultante de um processo que tem como motor histórico a luta de classes, mas seria inspirado no modelo econômico antigo, especialmente aquele defendido por Aristóteles. Mesmo repudiando o peculiar autoritarismo da época, o modelo antigo - baseado no valor de uso e, por isso, estruturado em forte organização central serviu a Marx como parâmetro para sua crítica ao despotismo da economia de mercado, que tem na estrutura da fábrica ou da grande indústria seu melhor exemplo.

Alan Gilbert (1992, p. 309) é ainda mais enfático na aproximação entre Marx e Aristóteles, a partir da teoria moral: "Alguns dos mais originais e profundos argumentos [de Marx] contra o capitalismo são de inspiração aristotélica ou eudaimonista". Como um bom crente no poder da teoria moral, Gilbert se mostra preocupado com a displicência daqueles marxistas, que, ao centrarem sua atenção nas análises de Marx sobre as instituiçôes econômicas e políticas modernas, perderam a oportunidade de ressaltar seus elementos clássicos, especialmente a ética aristotélica, a qual, em boa parte, fundamenta a teoria moral subjacente aos julgamentos marxianos.

Joseph Margolis (1992, p. 330) prefere ressaltar as diferenças entre Aristóteles e Marx a partir de suas respectivas antropologias. Defende que o “[...] núcleo do pensamento de Marx que tem sido pouco abalado pelas recentes reviravoltas políticas e econômicas certamente deve incluir sua noção de práxis", porém, enfatiza:

A verdade é que Marx rejeita a concepção aristotélica de homem e da práxis, e ele faz isso de uma maneira que depende de consideraçóes mais profundas do que aquelas que o aproximam do zôom poltikon aristotélico. [...] Existe a conexấo com Aristóteles, mas é totalmente superficial. A ligação de Marx com Aristóteles envolve apenas a apreensão de um ponto de partida útil, qualquer alegação de laços mais estreitos seria inteiramente enganosa. (MARGOLIS, 1992, p. 331). 
Segundo Margolis (1992), o ser genérico no jovem Marx é histórico, implica relação indissolúvel entre atividade prática e teórica, portanto, é totalmente oposto à essência imutável da natureza humana de Aristóteles, que de modo algum poderia assimilar a historicidade. Nos Manuscritos econômicofilosóficos - texto permeado de reflexôes antropológicas e éticas e onde a teoria do valor-trabalho ainda não faz parte do arcabouço teórico marxiano -, Marx rejeita Aristóteles, juntamente com Feuerbach. Portanto, antropologias completamente opostas inviabilizariam qualquer aproximaçáo séria entre os dois filósofos. Sendo mais um crente na teoria moral e sem compreender o que Marx realmente buscou em Aristóteles, só resta a Margolis defender que o abismo entre os dois filósofos é intransponível.

Mesmo sem buscar aproximaçóes ou discrepâncias entre ambos os filósofos, Leandro Konder pode ajudar a entender de que modo Marx busca a síntese entre prâxis e poíesis. Fazendo uma retrospectiva da palavra prâxis ao longo da história, Konder (1992) explica que, com a ascensão da burguesia, desde o momento em que ela passa a dispor dos instrumentos práticos e teóricos necessários para estruturar o modo de produção capitalista, houve a revalorização da atividade produtora de objetos materiais. A economia política clássica passou a sublinhar a importância do trabalho, no entanto, não o fazia do ponto de vista dos trabalhadores, não podendo realizar a síntese entre prâxis e poíesis: "Quando a ênfase era posta na poíesis, a prâxis (a atividade política) era desprezada; e, quando se reconhecia a significação humana da prâxis (o poder da cidadania), isso se dava em detrimento da poíesis" (KONDER, 1992, p. 102). É com Marx que o proletariado se torna o portador material da revolução, capaz de superar a sociedade burguesa com todas suas cisóes, dando assim novo significado à prâxis e à poiesis, náo mais limitado à prática ou à atividade. Dessa forma, o trabalho, por um lado, é a atividade livre produtiva (poíesis) voltada a um fim, permitindo ao homem transformar a natureza e se transformar, diferentemente da atividade espontânea dos animais, por isso é a fonte do poder de decisão. Por outro, é também prâxis, que, para se tornar humana, precisa ser realizada por um sujeito mais livre e mais consciente, é a atividade que precisa da teoria (KONDER, 1992).

Nesse sentido, para Booth, Gilbert e Margolis, o trabalho é central tanto para indicar semelhanças quanto diferenças entre Aristóteles e Marx, ainda que seja sempre sob o ponto de vista ético, político ou antropológico. Qualquer produção envolve trabalho, porém, do ponto de vista aristotélico - e grego em geral -, trabalho é sempre algo específico, é determinada habilidade. 
Ostenta um aspecto pedagógico e moral, mas não é categoria autônoma, a ponto de associá-la exclusiva e fundamentalmente à economia e menos ainda a qualquer atividade que guarde a premissa de transformação social ou progresso político. A característica que predomina em todos os trabalhos é o fato de ser atividade penosa e desgastante, moralmente inferior às atividades políticas, não podendo, dessa forma, ser enaltecida por Aristóteles ou ter lugar destacado no mundo da política antiga.

A separação entre ação e produção, entre política e crematística, juntamente com a concepção pejorativa do trabalho, poderia construir um fosso filosófico intransponível entre Aristóteles e Marx. Entretanto, o conceito de práxis ainda é visto como uma ponte entre eles, especialmente com a derrocada do comunismo real e, consequentemente, do alegado fracasso dos postulados econômicos marxianos. Não é difícil entender os motivos, afinal, Marx apresenta o trabalho sob duas perspectivas que reúnem o que em Aristóteles estavam bem separados: o trabalho como atividade que dá conta das necessidades básicas do homem, semelhante à poíesis; e o trabalho que realiza as potencialidades humanas, que guarda muitos aspectos da prâxis aristotélica, capaz de criar as condiçóes para a liberdade. $\mathrm{O}$ trabalho não é um mal necessário ou apenas instrumento de correção moral: é a atividade normal da vida, um dos fatores que permite a Marx confirmar a economia como a base real nas diversas formaçôes socioeconômicas, revelando uma importante inversão temática na história da filosofia. De acordo com os filósofos da moral, além de tentar reunir prâxis e poíesis no trabalho, em certos momentos, Marx se apropria da linguagem aristotélica.

\section{ATO, POTÊNCIA, TRABALHO E FORÇA DE TRABALHO}

Outro par conceitual muito caro a Aristóteles, e aludido como fator de aproximação com Marx, é aquele que expressa um dos vários modos de se dizer o ser: em ato e em potência. Na Metafísica (1046a11), Aristóteles explica que potência é uma força - ativa ou passiva - para promover movimento ou mudança em outro ou em si mesmo enquanto outro. Há vários tipos de potência: ativa; passiva; apática (resistência à mudança para pior); para agir bem, para receber bem (o modo próprio); racional; e não-racional. Com eles, Aristóteles pôde esclarecer, por exemplo, como os cidadãos (a matéria) são adequados para sofrer ou executar uma ação conforme as condiçóes e os limites. Há ainda a privaçáo (stéresis), ausência de potência tanto para fazer quanto 
para sofrer algo correspondente àquilo que está sendo avaliado. A privação não é pura negação, absoluta ausência da coisa. Pressupóe a existência de algumas propriedades e náo de outras, as quais se atualizam ou não, conforme o modo (total ou parcial), o tempo e o ambiente.

A potência racional mantém forte relação com a ação, porque inclui em sua definição a faculdade de escolha, própria da alma intelectiva e que, por isso, guarda a capacidade para produzir contrários (enantía), permitindo escolher fazer ou não algo determinado. Política e economia, por serem conduzidas por seres com potências racionais, podem cumprir ou não o seu fim próprio de acordo com as condiçôes necessárias para a atualização das diferentes potências, ou podem deturpar sua finalidade. Por exemplo, o médico ou qualquer outro profissional pode cumprir o fim próprio da sua função, ou pode visar ao rendimento monetário e apenas secundariamente a execuçáo da atividade (ação ou produção). A realização da potência e sua privação não refletem a mera possibilidade de fazer ou não fazer, mas de fazer principalmente conforme o que melhor convém à realização da essência, ao conteúdo da definição da coisa; somente depois de encerradas as possibilidades do aspecto positivo, ela escolhe entre o aspecto positivo e sua privação, caso contrário, o conceito de ato seria irrelevante e a ciência que almeja o bem da cidade seria mera especulaçáo intelectual. A ciência tem como fundamento o lógos que pode expressar o aspecto positivo (efetivo) e negativo (oposto), mas, como não há contrários coexistindo simultaneamente, apenas sucessivamente, não há anulação recíproca, porque há sempre um sujeito (bypokeimenon) a partir do qual eles passam a existir. Uma vez que não há um sujeito capaz de gerar simultaneamente a coisa e sua privação, os contrários não aparecem ao mesmo tempo no mesmo sujeito, apenas sucessivamente. Náo surgem igualmente de um modo qualquer: há primeiro a coisa, depois sua privação e, se não houver a coisa efetiva, não haverá sua privação. A existência de contrários está atrelada ainda à avaliaçáo das condiçóes internas (desejo, escolha) e externas (tempo, ambiente), as quais permitem ao sujeito considerar a atualização, a realização possível das potências, pois, apesar de a potência não ser algo totalmente desenvolvido, sua realização é necessária, mas não é ilimitada nem sustentada por princípios ontológicos mecanicistas.

Numa passagem de $O$ capital, Marx usa ato e potência para explicar que o histórico processo de alienação, seu surgimento e sua superação tornamse possíveis devido ao duplo caráter do trabalho: 
A utilização da força de trabalho é o próprio trabalho. O comprador da força de trabalho a consome ao fazer trabalhar o vendedor dela. O último torna-se, desse modo, $a c t u$, a força de trabalho realmente ativa, o que antes era apenas potentia. (MARX, 1985, p. 149).

A força de trabalho é a capacidade humana de realizar um trabalho útil, por isso, aumenta o valor das mercadorias, enquanto o trabalho é a efetivação dessa capacidade produtiva. A adoção da linguagem aristotélica juntamente com os aspectos da potência ligados à política chamou a atenção de alguns filósofos para a incorporação do ato/potência por Marx, especialmente no que diz respeito às transformaçóes sociais advindas das potencialidades próprias do trabalho, pois a produçáo é a passagem de uma potência (um conjunto de condiçóes necessárias) ao ato (a realização daquelas condiçóes), de acordo com um planejamento a ser seguido, embora nem sempre passível de ser controlado em seus detalhes. Esta é a aposta de Allen Wood, ao enfatizar a linguagem aristotélica na afirmação de Marx sobre a atualização da essência genérica, a sociabilidade humana, descrita especialmente nos Manuscritos:

Mas a natureza social ou comunitária do ser humano é apenas uma parte do que Marx quer dizer quando insiste que minha autorrealização é a atualização da minha essência humana. Ele quer dizer também que o modo de vida verdadeiramente humano é aquele que se manifesta ou exemplifica certas coisas, e que essas coisas são determinadas por minha essência. A linguagem de Marx nesse ponto é a linguagem aristotélica da potência e ato. (WOOD, 2004, p. 22-23).

De acordo com Wood, tanto para Marx quanto para Aristóteles, a realização da vida genuinamente humana consiste em desenvolver e efetivar as potencialidades num conjunto de atividades humanas adequadas à natureza humana, o que, para Marx, só seria possível no comunismo, onde o proletariado finalmente superaria a alienação. Haveria então uma essência humana a qual seria desvelada à medida que se atualizassem as potencialidades humanas e, como este é um pensamento tipicamente aristotélico, a aproximação entre os dois filósofos se torna evidente.

O problema nessa tese de Wood é que a transformação que a poiesis, por meio do trabalho, seria capaz de promover não tem para Aristóteles a característica de transformação estrutural, ou revolucionária, pelo contrário, a passagem da potência ao ato obedece a um plano pré-determinado que guarda 
e aguarda as condiçôes necessárias para se realizar. Esse plano pré-determinado não será cumprido à revelia de qualquer condição interna ou externa, porque há uma linearidade que predomina. Além de ato e potência guardarem certa continuidade essencial, Aristóteles não poderia atribuir à produção o poder de transformação social, sobretudo por não fazer ideia da distinção entre trabalho e força de trabalho, dada as diferenças sociais entre senhor e escravo, trabalhador e cidadão. Mas, na dialética marxiana, as revoluções são o ponto culminante da mudança, marcam a atualização das potencialidades humanas que, por sua vez, dependem da história das formas de produção. As capacidades humanas vêm à tona, quando algo é produzido, ação e produção não obedecem a um plano linearmente pré-determinado, sem desvios, pelo contrário, o caminho percorrido é permeado de contradiçôes, aliás, se realiza nas contradiçôes. Por conseguinte, em parte, concordamos com o importante reparo de Margolis (1992, p. 340): “É bem verdade que a 'linguagem' de Marx é 'aristotélica’, mas seu pensamento não.” Na formulaçáo aristotélica, a ruptura entre potência e ato, mesmo nas relações humanas, não é elemento estruturante, pois o movimento é um desdobramento linear, enquanto, em Marx, prevalece a tendência de uma natureza humana historicamente construída.

Tanto Margolis como Wood estâo preocupados com a questão moral: a diferença é que Margolis reconhece que o uso do conceito do ser genérico, nos Manuscritos, era impregnado de elementos morais e, por isso, foi sendo substituído por uma crítica de um modo de produção específico. Ou seja, enquanto Wood acredita que Marx é um crítico não apenas da moral burguesa, mas de toda moral, Margolis defende que Marx é crítico de uma pretensa moral essencialista, típica do aristotelismo.

No entanto, é preciso admitir que, se, por um lado, Marx se distancia de Aristóteles ao não estipular um bem supremo específico (a vida contemplativa) ou uma finalidade fixa, por outro, ao estabelecer o socialismo como parâmetro histórico para a supressão de toda forma de alienação, Marx sustenta uma teleologia fundamentada na realização harmônica das finalidades do homem. Assim como pretendeu rejeitar qualquer proposta de essência humana, Marx, segundo Lucio Colletti, também lutou para extirpar qualquer ideia de um curso intencional da história:

É claro que dizer alienação é dizer dialética. E que ambas implicam processo teleológico, finalista. De fato, como não há alienação que não pressuponha redenção, emancipação, também não há cisão ou contradição dialética fora da finalidade de sua recomposição na unidade. (COLLETTI, 1983, p. 71). 
Sem entrar na espinhosa disputa sobre a cientificidade da dialética e sua relação com ideologia e alienação, destacamos apenas a amplitude dos conceitos de ato e potência que, devido a suas inúmeras possibilidades de aplicação, correm o risco de se tornarem vazios. Nessa perspectiva, arriscamos afirmar que ato e potência são assumidos por Marx em, pelo menos, dois sentidos: o primeiro, quando parecem refletir o duplo caráter do trabalho (força de trabalho/potência, trabalho/ato); o segundo aparece na constante transformação que as forças produtivas ou a própria produção promove ao longo da história nas diversas formaçóes socioeconômicas como se obedecesse a um plano maior, algo que se atualiza de modo impessoal. No primeiro sentido, Marx (1985, p. 149) explica que o trabalho é um processo entre homem e natureza, em que "[...] o homem, por sua própria ação media, regula e controla seu metabolismo com a natureza. [...] Ele desenvolve as potências nela adormecidas e submete o jogo de suas forças ao próprio domínio". O trabalho, considerado independentemente de qualquer forma social específica, é atividade que transforma a natureza bruta e com isso transforma o próprio homem. Ao mesmo tempo, de acordo com a maneira como são satisfeitas as necessidades por meio da produção, o trabalho recebe uma caracterização social determinada, se atualiza de um modo específico.

O segundo sentido transparece na dupla face do conceito de força de trabalho: num primeiro momento, é uma mercadoria igual a qualquer outra, pois tem seu valor de uso (sua utilidade, porque é capaz de produzir algo) e seu valor (para ser trocada por outra coisa que tenha o mesmo valor). Entretanto, num segundo momento, a força de trabalho mostra sua peculiaridade: aumentar o valor das mercadorias. Isso ocorre porque o valor que é pago pela força de trabalho (potência) é menor do que o valor do trabalho extraído (ato) dessa força de trabalho. O trabalhador, em suma, é pago pelo valor de troca de sua força de trabalho e aliena o valor de uso dessa mesma força de trabalho (MARX, 1985, p. 167). Tal distorção expressa a armadilha e o fundamento do capitalismo, o fato de o trabalhador e o seu trabalho já pertencerem a outro, desde o começo. Se o problema é ontológico - separação entre produto e produtor -, não teria sentido concordar, portanto, com propostas reformistas limitadas a melhorias salariais ou à intervenção do Estado, pois o salário é apenas a contrapartida ou a expressão da expropriação inicial e total do trabalhador que já pertence ao capital, antes que se venda ao capitalista. $\mathrm{O}$ trabalhador é pago pela venda de sua força de trabalho e, mesmo que aumentasse o preço dessa mercadoria ou que houvesse um aumento da riqueza material, as relações de dependência se manteriam. Somente com a restituição da propriedade 
por meio da não intermediação externa entre produtos e produtores é que o responsável direto pela geração da riqueza não venderá sua força de trabalho, não entregará a outro a capacidade de criação de um novo mundo, que é, justamente, o que diferencia o homem dos outros seres. É aqui que se pode entender o segundo sentido do princípio que permeia a passagem da potência ao ato, a ideia de que o socialismo pressupóe necessariamente o capitalismo e a alienação que lhe é inerente e, ao mesmo tempo, faz parte do trampolim para a tomada de consciência da classe trabalhadora. O processo de alienação tem a potência para gerar seu contrário, já que o trabalho excedente não pago é a principal força do modo de produção capitalista: "O grande sentido histórico do capital é criar este trabalho excedente, trabalho supérfluo do ponto de vista do mero valor de uso, da mera subsistência” (MARX, 1997, p. 266). O capital - relação de expropriação fundamentada na mais-valia - aspira ao dinheiro, forma universal da riqueza, todavia, nessa busca incessante,

[...] leva o trabalho a ultrapassar os limites de sua necessidade natural e cria assim os elementos materiais para o desenvolvimento da rica individualidade, tâo multilateral em sua produção como em seu consumo e cujo trabalho, por isso mesmo, tampouco se apresenta como trabalho, mas como desenvolvimento pleno da atividade em si, na qual é superada a necessidade natural em sua forma direta, porque a necessidade natural é substituída por aquela produzida historicamente. (MARX, 1997, p. 267).

A “missão" do capital é desenvolver as forças produtivas sociais, de modo a romper as relações de produção existentes, ultrapassar todas as relações de dominação direta para que o trabalho não seja apenas natural, mas se torne trabalho histórico, social. Enquanto o artesão feudal executa um trabalho determinado numa relação com um mestre determinado, o trabalho assalariado, por ser abstrato (totalmente indiferente às particularidades, porém capaz de qualquer determinaçáo) se contrapóe ao capital, que, por sua vez, se contrapóe a qualquer trabalho determinado dos assalariados. O que o assalariado tem à disposição é uma massa informe, uma força que serve e supera o capital. $\mathrm{O}$ escravo da antiguidade tem valor de troca, porque é incorporado totalmente, pertence inteiramente a outro, enquanto o "[...] trabalhador livre não tem valor algum, somente a disposição sobre seu trabalho, por meio do intercâmbio que é feito com ele mesmo, é que tem valor" (MARX, 1997, p. 232). Sua ausência de valor e sua desvalorização são um avanço, pois colocam o trabalhador formalmente como pessoa que, mesmo à margem de seu trabalho, é algo para si mesmo, diferentemente do escravo e do servo, os quais nada são 
quando não trabalham. Força de trabalho é uma mercadoria típica do assalariado, ao passo que o escravo e o servo não produzem mercadoria alguma, são apenas a própria força de trabalho, não havendo nestes qualquer distinção entre potência e ato; eles não têm algo que possa ser alienado: são alienados por inteiro. Juntamente com a análise das contradições imanentes ao capitalismo, Marx aposta nas potencialidades do trabalho para avaliar e criticar a situação do trabalhador e eleger o trabalho como o cerne de sua teleologia material. Portanto, ainda que a revolução econômica não se limite à socializaçáo dos meios de produção - eliminaçáo da propriedade privada dos meios de produção e da exploração ao trabalhador - e que a expropriação do capitalista seja uma ação política, esta é derivada do choque das relaçôes de produção (formas político-jurídicas: a superestrutura) com as forças de produção (os meios de produção juntamente com a força de trabalho: a estrutura).

Se o trabalho agrega ou não as condições para a ação política, se é ou não capaz de criar a consciência revolucionária, esse é mais um daqueles problemas filosóficos insolúveis. O certo é que, sem desprezar as influências filosóficas e, ao mesmo tempo, sem cair na nostalgia moralista, Marx ainda acredita nas potencialidades da ação política, porém, percebe sua exaustão nos moldes antigos; prova disso é nunca ter formulado uma teoria política ou do Estado, visto que seria inócua na pós-Revolução Industrial. O fato de agregar no trabalho as potencialidades antes restritas à ação remete diretamente à mudança de enfoque filosófico, colocando a Economia como novo instrumento para a análise crítica ao capitalismo. Enquanto, para Aristóteles, o trabalho é uma habilidade, uma atividade penosa cuja função específica visa apenas a alguma finalidade extrínseca, para Marx, é a chave para fundamentar a economia política. Dessa forma, se já não era possível para Aristóteles imaginar o trabalho como categoria geral, nada mais distante de sua realidade do que separar essa atividade em dois momentos intrinsecamente conectados: em potência e em ato.

\section{A INFLUÊNCIA FUNDAMENTAL}

De acordo com Marx, o mais relevante em Aristóteles é a investigação que remete às origens da economia política, a distinção entre valor de troca e valor de uso. De modo geral, os filósofos da moral invertem as contribuiçóes de Marx à história da filosofia e com isso ignoram os verdadeiros elementos aristotélicos no discurso marxiano, explicitados, inclusive, nas citaçóes literais. Embora a menção direta a um autor, ou sua ausência, não seja prova definitiva 
da influência exercida, não podemos deixar de notar que, nos Manuscritos, texto onde se poderia esperar a relação com a ética e antropologia aristotélica, há apenas uma citação direta ao Estagirita e pouco relevantes. Ou seja, o texto em que os vários estudiosos enfatizam a práxis marxiana é onde menos Aristóteles é citado, ao contrário dos textos de maturidade, nos quais é citado várias vezes, em momentos de renitente disputa teórica acerca do valor. Inicialmente, Marx, nos Manuscritos econômico-filosóficos (1993) aceita a distinção valor de uso/valor de troca - explicitada por Aristóteles na equiparaçáo entre casa e sapatos, na sua busca do padrão de comensurabilidade -, depois, em $O$ capital (1985), acrescenta que o valor de troca é apenas um modo de manifestação do valor contido na mercadoria. Marx (1985, p. 57) mostra como Aristóteles percebeu que o dinheiro torna as mercadorias aparentemente comensuráveis, porque o valor de troca das mercadorias está suposto em seus preços, contudo, observou também que as mercadorias, "[...] essas coisas distintas, medidas pelo dinheiro, constituem grandezas totalmente incomensuráveis”. O dinheiro serve como medida objetiva, externa, portanto, é passível de quantificação e por sua praticidade cotidiana facilita o intercâmbio entre diferentes mercadorias, porém, segundo Marx, Aristóteles compreende que o dinheiro não é o padrão de comensurabilidade por três motivos: primeiro, porque já existia troca antes do uso do dinheiro; segundo, porque na verdade não é possível comensurar coisas táo diferentes; terceiro, porque o que Aristóteles procura

[...] é a unidade das mercadorias como valor de troca, o que, como grego da Antiguidade, não tinha possibilidade de encontrar. Entretanto, contorna a dificuldade permitindo ao dinheiro a funçáo de medida daquilo que, em si, é incomensurável, uma vez que isso se torna necessário na prática. 'Na verdade, é impossível que coisas táo diferentes sejam comensuráveis, mas isso é necessário na prática. (MARX, 1985, p. 57).

A verdadeira causa, a ausência do conceito de valor, seria algo que estaria para além das condiçóes históricas da Antiguidade, inalcançável mesmo para Aristóteles, que vivia num modo de produção no qual ainda não predominavam relaçóes entre mercadorias. $\mathrm{O}$ processo de troca não era suficientemente desenvolvido e sistemático, a troca não era a forma típica do processo de produção, por conseguinte, nem mesmo a genialidade de Aristóteles poderia

${ }^{5} \mathrm{O}$ parágrafo em que Aristóteles é inserido está no capítulo sobre propriedade privada e comunismo. É citado apenas para fundamentar a autarquia existencial em que um ser independente, autárquico, deve a si mesmo sua existência e não a outro ser pretensamente responsável por sua criação (MARX, 1993, p. 203). 
conceituar o trabalho abstrato, o fundamento do valor, pois não era uma categoria isolada. Ainda que tenha suscitado o trabalho como um dos elementos para definir o padrão de equivalência na troca dos produtos, o máximo que ele consegue enxergar no trabalho é seu aspecto pedagógico e moral. Marx torna a hesitação aristotélica o ponto de partida, não de críticas antropológicas, éticas ou políticas totalmente caducas, mas de uma longa e tortuosa trajetória em busca de fundamentação à crítica da economia política.

Sem discutir aqui os fundamentos históricos da teoria do valor, apenas ressaltamos que o verdadeiro ponto de partida para Marx é a análise aristotélica sobre o valor de troca, o que não significa que as questóes éticas não sejam relevantes ou que a análise aristotélica sobre o valor de troca possa ser, em seu todo, abarcada por Marx ou por qualquer outro teórico.

Concordamos com Benedetto Croce, quando afirma que, para Marx, a questão social não era uma questão ética e que a análise do capitalismo era importante para o estabelecimento das leis que regulam uma determinada forma de sociedade, não a denúncia de um roubo. Segundo Croce (2007, p. 92), Marx reconhece a impotência das condenaçóes morais contra os dominadores, sejam eles donos de escravos, senhores feudais ou capitalistas burgueses, pois “[...] é inútil propor problemas que nenhum esforço poderá resolver e, portanto, são absurdos”. Por outro lado, quando as relaçôes de sujeição não necessárias para a ordem social em geral, são simplesmente necessárias ao seu estágio histórico, e quando surgem novas condiçôes para sua abolição, a condenação moral está justificada e pode influir para acelerar o processo de dissolução e para varrer os restos do passado. Mesmo assim, "[...] a moral condena o que já está condenado pela história”. O conceito de valor-trabalho não é um ideal e nem mesmo é ético, não é uma lei moral: "[a] suposta igualdade do valor e do trabalho não tem natureza moral e não ocasiona nenhuma regra moral, pois não se refere a uma relação entre seres humanos" (CROCE, 2007, p. 146).

Também Mandel (1989, p. 243) explica que Marx elaborou uma “[...] teoria econômica com base na indignação moral. Mas a verdade é que com ele a rigorosa análise econômica permitiu pela primeira vez, estabelecer a indignação moral na base de granito da ciência”. Marx foi movido por preocupaçóes morais, mas a necessária superação do valor não acontecerá por meio de reforma jurídica ou moral, já que o valor é material, portanto, a revolução tem que se dar pela superação da troca mercantil. Isso significa que reformas morais, políticas ou mesmo econômicas que pretendam delimitar o uso do dinheiro são inócuas: “[...] enquanto o dinheiro permanecer como uma relação 
de produção essencial, ninguém poderá suprimir suas contradiçóes inerentes" (MARX, 1985, p. 46).

\section{CONSIDERAÇÓES FINAIS}

Seria inútil negar semelhanças teóricas entre Aristóteles e Marx, afinal, é possível criar aproximaçóes entre filósofos de vertentes totalmente díspares e de épocas infinitamente distantes. Superficialmente, é possível constatar a presença de vários princípios e conceitos aristotélicos em Marx, porém, sempre com muitas ressalvas, assumindo relevância maior somente na medida em que as questôes de economia levantadas por Aristóteles podem ser incorporadas à economia política marxiana. Sobre isso é preciso considerar ao menos dois fatores. Primeiro, se foi principalmente a partir da Revolução Industrial que a economia passou a ser um dos aspectos determinantes da vida social, tornando a economia política o instrumental conceitual necessário para fundamentar a crítica marxiana ao modo de produção capitalista, não teria sentido buscar sua aproximação com Aristóteles, com base, prioritariamente, na política ou na ética, pois, quando exercem influência significativa, ocupam lugar secundário. Se isso não for levado em conta, Marx se torna apenas mais um moralista com preceitos e princípios humanistas muito vagos e passíveis de aplicação em qualquer formação socioeconômica. Para Marx, a derrocada do último modo de produção aniquilador das faculdades humanas não tem como causa uma crise moral, política ou antropológica. São as próprias contradiçôes do capitalismo que determinarão sua aniquilação. $\mathrm{O}$ capital está fundamentado num mecanismo autodestrutivo, um modo de produção que "[d]iminui, assim, o tempo de trabalho na forma de tempo de trabalho necessário, para aumentá-lo na forma de trabalho excedente" (MARX, 1997, p. 229). O desenvolvimento máximo da força produtiva ao lado da expansão máxima da riqueza existente coincide com a depreciação do capital, a degradação do trabalhador e o enfraquecimento absoluto de suas faculdades vitais. A causa da crise está na proporção inversa entre a taxa de lucro e o incremento da mais-valia relativa (MARX, 1997).

O segundo fator a se destacar é que, na principal obra de Marx, $O$ capital, as mençóes a Aristóteles são importantes, mas remetem à investigação sobre economia. Os elementos éticos ou políticos aristotélicos estão presentes somente na medida em que servem de apoio aos fundamentos históricos da economia política. 
Reconhecer a contribuição teórica de Aristóteles à economia política de Marx não significa afirmar que os dois filósofos sustentam teorias muito semelhantes, como se Aristóteles tivesse antecipado a teoria do valor-trabalho. A avaliação que Marx faz do modo como se organiza a produção antiga, ressaltando as diferenças estruturais com a formação capitalista, revela bem sua preocupação em esclarecer as singularidades daquelas condiçóes sociais e econômicas em que Aristóteles se encontrava. Somente a avaliação e a interpretação que Marx faz tanto da economia política antiga (grau de desenvolvimento econômico, relaçóes de produção, forças produtivas) quanto daquela dispersamente apresentada por Aristóteles poderão esclarecer a relevante relação teórica entre dois filósofos, buscando os elementos da economia política aristotélica os quais são incorporados por Marx, e de que modo isso ocorre, algo pouco compreendido pelos filósofos da moral.

LIMA, Alexandre. Aristotelian Ethics in Marx? Trans/Form/Ação, Marília, v. 37, n. 2, p. 11-30, Maio/Ago., 2014.

\begin{abstract}
Some philosophers and economists have sought an ethical basis for the economy, to subordinate it to politics, and even to appeal for an approximation between Marx and Aristotle based on a theory of praxis. This article analyzes in what sense the Aristotelian concepts of action, production, act, and power influence Marx. It affirms, contrary to many moral philosophers, that it is Aristotle's investigations of the economy that are the basis of the criticism of political economy developed by Marx, while Aristotelian ethics and politics are only secondary to Marxian theory.
\end{abstract}

KEYWORDS: Marx. Aristotle. Ethics. Economy. Praxis.

\title{
REFERÊNCIAS
}

ARISTÓTELES. Éthique à Nicomaque. Traduction et commentaire par J. Tricot. Paris: J. Vrin, 2007.

. Eudemian ethics (Ethica Eudemia). Translated by Joseph Solomoon. Editor W. D. Ross. Oxford: Oxford University Press, 1953.

1982. . Metafísica. Tradução de Valentín Garcia Yebra. 2. ed. trilingue. Madrid: Gredos, . La politique. Traduction et commentaire par J. Tricot. Paris: J. Vrin, 1977. 
BOOTH, W. J. Households, markets, and firms. In: MCCARTHY, George E. (Ed.). Marx and Aristotle: Nineteenth-century German Social Theory and Classical Antiquity. Maryland: Rowman \& Littlefield, 1992, p. 243-274.

COLLETTI, L. Ultrapassando o marxismo. Tradução de Eduardo Brandão. Rio de Janeiro: Forense Universitária, 1983.

CRESPO, R. F. The ontology of 'the economic': an Aristotelian analysis. Cambridge Journal of Economics, v. 30, n. 5, p.767-781, 2006.

CROCE, B. Materialismo histórico e economia marxista. Traduçáo de Luis Washington. São Paulo: Centauro, 2007.

GILBERT, A. Marx's moral realism: eudaimonism and moral progress. In: MCCARTHY, George E. (Ed.). Marx and Aristotle: nineteenth-century German social theory and classical antiquity. Maryland: Rowman \& Littlefield, 1992. p. 303-328.

KONDER, L. O futuro da filosofia da práxis: o pensamento de Marx no século XXI. Rio de Janeiro: Paz e Terra, 1992.

MACCARTHY, G. E. (Ed.) Marx and Aristotle: nineteenth-century German social theory and classical antiquity. Maryland: Rowman \& Littlefield, 1992.

MANDEL, E. Tratado de economia marxista. 3. ed. México: Era, 1989. Tomos I-III.

MARGOLIS, J. Praxis and meaning: Marx's species-being and Aristotle's political animal. In: MCCARTHY, George E. (Ed.). Marx and Aristotle: nineteenth-century German social theory and classical antiquity. Maryland: Rowman \& Littlefield, 1992. p. 329-356.

MARX, K. Elementos fundamentales para la critica de la economia politica (Grundrisse) 1857-1858. Tradução de José Aricó, Miguel Murmis e Pedro Scaron. 10. ed. México: Siglo Veintiuno, 1997. v. I-III.

. O Capital: crítica da economia política. Tradução de Regis Barbosa e Flávio R. Kothe. 2. ed. São Paulo: Nova Cultural, 1985. Livro I. (Os economistas).

1993.

Manuscritos econômico-filosóficos. Tradução de Artur Morão. Lisboa: Edições 70,

POPPER, K. A sociedade aberta e seus inimigos. Tradução de Milton Amado. 3. ed. Belo Horizonte: Itatiaia, 1987.

WOOD, A. W. Karl Marx. 2. ed. London: Routledge and Kegan Paul, 2004.

Recebido em: 11/12/13

Aceito em: 01/02/14 
LIMA, A. 